\title{
KARAKTERISTIK SOSIO-DEMOGRAFI IBU TERHADAP PROPORSI PEMBERIAN ASI EKSKLUSIF PADA BALITA USIA DIATAS 6 BULAN HINGGA 24 BULAN DI DESA PEKUTATAN, KECAMATAN PEKUTATAN, KABUPATEN JEMBRANA BALI TAHUN 2015
}

\author{
Jeevitra Gunasegaran, I Putu Ardinata, Gythrie Kartikason \\ Program Studi Pendidikan Dokter, Fakultas Kedokteran Universitas Udayana \\ (yantra12@yahoo.com)
}

\section{ABSTRAK}

Cakupan nasional pemberian ASI eksklusif Tahun 2010 sebesar 15,3\%, belum mencapai target nasional yaitu $80 \%$. UNICEF menyatakan bahwa sebanyak 30.000 kematian bayi di Indonesia dan 10 juta kematian anak balita di dunia setiap tahunnya dapat dicegah melalui pemberian Air Susu Ibu (ASI) secara eksklusif selama enam bulan sejak lahir tanpa harus memberikan makanan serta minuman tambahan kepada bayi. ${ }^{1}$ ASI menyediakan energi dan nutisi yang dibutuhkan oleh bayi selama bulan-bulan pertama kehidupan dan terus berlanjut hingga usia 2 tahun. ${ }^{2}$

Penelitian ini menggunakan metode cross-sectional dekriptif. Sampel penelitian adalah ibu yang memiliki balita usia 6 bulan sampai 24 bulan yang diambil menggunakan simple random sampling yaitu sejumlah 52 orang. Penelitian ini dilaksanakan di desa Pekutatan, kecamatan Pekutatan, kabupaten Jembrana, pada bulan November 2015. Pengumpulan data menggunakan kuesioner. Data yang didapat dianalisi secara univariate dan bivarite kemudian disajikan dalam bentuk tabel. Hasil dan simpulan penelitian ini adalah proporsi pemberian ASI eksklusif sebesar 30,8 persen. Proporsi pemberian ASI eksklusif pada balita usia 6-24 bulan di berdasarkan tingkat pengetahuan yaitu sebesar $80,2 \%$ termasuk kategori baik, umur terbanyak pemberian ASI eksklusif yaitu diatas 18-30 tahun (76,9\%), paritas terbanyak yaitu kategori kurang dari $2(63,5 \%)$, dukungan suami terbanyak yaitu kategori baik $(53,8 \%)$, dan dukungan petugas kesehatan terbanyak yaitu kategori baik (78,8\%).

Kata kunci : ASI eksklusif, proporsi, desa Pekutatan, balita usia 6-24 bulan.

\section{SOCIO-DEMOGRAPHIC CHARACTERISTICS OF THE MOTHER OF PROPORTION OF EXCLUSIVE BREASTFEEDING IN CHILDREN AGE 6-24 MONTHS IN THE PEKUTATAN VILLAGE, PEKUTATAN SUBDISTRICT, JEMBRANA REGENCY, BALI 2015}

\section{ABSTRACT}

National coverage of exclusive breastfeeding in 2010 amounted to 15.3\%, has not reached the national target of $80 \%$. UNICEF said that as many as 30,000 infant deaths in Indonesia and 10 million deaths of children under five in the world each year could be prevented through breastfeeding (breastfeeding) exclusively for six months from birth without having to provide additional food and drink to the baby. ${ }^{1}$ Provides energy and nutisi needed by infants during the first months of life and continued until the age of 2 years. ${ }^{2}$

This study used a cross-sectional descriptive design. Samples are mothers who have children ages 6 months to 24 months are taken by using simple random sampling that total of 52 peoples. This research was conducted in the Pekutatan village, Pekutatan subdistrict, Jembrana regency, in November 2015. The data was collected using a questionnaire. The data was analyzed by univariate and bivarite then presented in tabular form.

Results and conclusions of this study was the proportion of exclusive breastfeeding at 30.8 percent. The proportion of exclusive breastfeeding in infants aged 6-24 months based on the knowledge level that is equal to $80.2 \%$ good category, the largest age exclusive breastfeeding is above $18-30$ years 
(76.9\%), the highest parity namely the category of less than $2(63.5 \%)$, ie the highest husband support both categories (53.8\%), and the support of most health workers are good category $(78.8 \%)$. Keywords : exclusive breastfeeding, proportion, Pekutatan village, children aged 6-24 months.

\section{PENDAHULUAN}

ASI eksklusif merupakan ASI yang diberikan kepada Bayi sejak dilahirkan selama 6 (enam) bulan, tanpa menambahkan dan/atau mengganti dengan makanan atau minuman lain. ASI eksklusif dianjurkan pada beberapa bulan pertama kehidupan karena ASI tidak terkontaminasi dan mengandung banyak gizi yang diperlukan anak pada umur tersebut. $^{3}$

Perhatian khusus diperlukan kepada anak-anak terutama usia 0-24 bulan karena usia tersebut merupakan periode emas tersebut dalam pertumbuhan dan perkembangan bayi, Maka dari itu pemberian nutrisi yang adekuat sangat diperlukan dalam rangka menurunkan angka morbiditas dan mortalitas anak, serta untuk mencapai tumbuh kembang yang optimal. Dan salah satu caranya adalah dengan pemberian ASI ekslusif. ${ }^{3}$

UNICEF menyatakan bahwa sebanyak 30.000 kematian bayi di Indonesia dan 10 juta kematian anak balita di dunia setiap tahunnya dapat dicegah melalui pemberian Air Susu Ibu (ASI) secara eksklusif selama enam bulan sejak lahir tanpa harus memberikan makanan serta minuman tambahan kepada bayi. ${ }^{1}$ ASI menyediakan energi dan nutisi yang dibutuhkan oleh bayi selama bulan-bulan pertama kehidupan dan terus berlanjut hingga usia 2 tahun. ${ }^{2}$ Setelah itu anak harus diberi makanan padat dan semi padat sebagai makanan tambahan selain ASI. ${ }^{4}$ Sedangkan di Indonesia pada tahun 2003 mengubah rekomendasi lamanya pemberian ASI eksklusif dari 4 bulan menjadi 6 bulan.

Berbagai manfaat diperoleh dari ASI yaitu dapat terlindungi dari penyakit infeksi, mendapatkan kebutuhan gizi yang sesuai dengan usianya, memperoleh stimulasi sensoris yang majemuk dari sentuhan/stimulasi taktil, stimulasi pendengaran melalui kata-kata yang didengarnya selama menyusui, stimulasi pengecapan dari rasa ASI dan stimulasi penciuman dari bau ibunya. ${ }^{6}$

Berdasarkan penelitian Rahmadhani, dkk dikatakan bahwa diare akut lebih sering pada bayi yang tidak mendapatkan ASI eksklusif (74,3\%) dibandingkan dengan bayi yang mendapat ASI eksklusif $(26,5 \%){ }^{6}$ Begitu pula dengan penelitian yang dilakukan oleh Ariefudin (2010) yang menyatakan bayi yang mendapatkan ASI ekslusif mengalami kejadian ISPA lebih sedikit (10,4\%) dibandingkan bayi yang diberikan ASI non eksklusif $(32,4 \%) .^{7}$

Meskipun banyak manfaat positif yang didapat dari pemberian ASI eksklusif ini, hanya terdapat $39 \%$ bayi kurang dari 6 bulan yang mendapat ASI eksklusif pada tahun 2012. Dan di beberapa negara pun pemberian ASI eksklusif juga masih jauh dari target pencapaian, termasuk di Indonesia sendiri. Menurut Survei Demografi Kesehatan Indonesia tahun 2013 bayi di bawah umur 6 bulan yang mendapat ASI eksklusif hanya sebesar $42 \%$. Angka tersebut masih jauh dari target yang sebesar $80 \% .^{8}$

Berdasarkan data dari Dinas Kesehatan Provinsi Bali, cakupan pemberian ASI eksklusif sangat fluktuatif dalam 6 tahun terakhir. Pada tahun 2009 cakupan ASI eksklusif adalah sebesar $46.25 \%$, pada tahun 2010 turun menjadi 36,54\%, tapi kembali naik tajam tahun 2011 menjadi 58,65\%. Pada tahun 2012 cakupan ASI eksklusif kembali naik menjadi 65,88\%.9 Pada tahun 2013, cakupan pemberian ASI eksklusif di Provinsi Bali kembali mengalami peningkatan menjadi 69,3\%. ${ }^{10}$ Sedangkan di Kecamatan Pekutatan, target pencapaian ASI eksklusif mencapai $72 \%$ yaitu dari 743 bayi, hanya 535 bayi yang baru mendapatkan ASI eksklusif bayi pada tahun 2014. Pencapaian ASI ekslusif di tahun 2014 ini mengalami penurunan dibandingkan tahun 2013 yaitu 80,78\%. ${ }^{11}$

Adapun kendala yang dihadapi dalam praktek pemberian ASI eksklusif yakni status keterampilan dan pengetahuan ibu, pekerjaan ibu sehari-hari, lama ibu bekerja, kesehatan ibu dan bayi, usia ibu menyusui, tingkat pendidikan, serta peran serta dari suami (breasfeeding father) dan dukungan dari anggota keluarga yang lain. ${ }^{12}$

Dari sekian banyak kendala tersebut di atas, sebagian besar hambatan untuk memberikan ASI eksklusif yakni kurangnya pengetahuan dan informasi yang tidak benar. Berdasarkan penelitian 
Lestari dkk (2013) di Lampung menyatakan bahwa ibu yang memiliki tingkat pengetahuan baik dapat memberikan ASI eksklusif lebih banyak (81,3\%) dibandingkan dengan yang tingkat pengetahuannya kurang (5,6\%). ${ }^{13}$ Berdasarkan uraian tersebut, maka peneliti tertarik untuk melakukan penelitian mengenai gambaran sosiodemografi ibu terhadap pemberian ASI eksklusif.

\section{METODELOGI PENELITIAN}

\section{Tempat dan Waktu Penelitian}

Penelitian ini dilakukan di Desa Pekutatan, Kecamatan Pekutatan, Kabupaten Jembrana pada bulan November 2015.

\section{Rancangan Penelitian}

Penelitian ini menggunakan rancangan penelitian cross sectional deskriptif yaitu dilakukan pengumpulan data untuk memperoleh proporsi pemberian ASI eksklusif pada bayi berusia $>6$ bulan hingga 24 bulan di desa Pekutatan, kecamatan Pekutatan, kabupaten Jembrana

\section{Populasi Penelitian}

Populasi dalam penelitian ini adalah semua ibu yang memiliki balita berusia $>6$ bulan hingga 24 bulan di desa Pekutatan, kecamatan Pekutatan, kabupaten Jembrana

\section{Kriteria Inklusi dan Kriteria Eksklusi Sampel}

Kriteria Inklusi:

Bayi dengan usia $>6$ bulan hingga 24 bulan, lahir cukup bulan dengan berat lahir normal.

Kriteria Eksklusi:

Bayi dengan usia $>6$ bulan hingga 24 bulan, lahir prematur dan ataupun dengan berat lahir rendah (BBLR).

\section{Kriteria Inklusi dan Kriteria Eksklusi Responden} Kriteria inklusi:

1. Ibu yang mempunyai bayi usia $>6$ bulan hingga 24 bulan dengan berat lahir normal dan bayi cukup bulan.

2. Ibu yang bersedia untuk diwawancarai.

3. Ibu yang mampu memberikan keterangan selama wawancara.

$\underline{\text { Kriteria eksklusi: }}$
1. Ibu yang mempunyai bayi usia $>6$ bulan hingga 24 bulan dengan bayi berat lahir rendah (BBLR) dan bayi kurang bulan.

2. Ibu yang tidak bersedia untuk diwawancarai.

3. Ibu yang tidak mampu memberikan keterangan selama wawancara.

\section{Besar dan Cara Pengambilan Sampel}

Jumlah Sampel

Sampel dalam penelitian ini diambil dengan menggunakan rumus:

$$
n=\frac{\mathrm{z}^{2}(\mathrm{pq})}{\mathrm{d}^{2}}
$$

\section{Keterangan:}

$\mathrm{n}$ : besar sampel (dengan populasi $>10.000$ )

$z$ : sama dengan 1,96 dengan confidence level $95 \%$

d : derajat kesalahan yang bisa ditolerir yaitu sebesar $10 \%$ atau 0,10

$\mathrm{p}$ : proporsi populasi digunakan $72 \%$ atau 0,72 , hasil ini didapat dari proporsi pemberian ASI eksklusif di Puskesmas Pekutatan I tahun 2014

$q$ : populasi tanpa atribut, $1-p=0,28$

$$
\begin{gathered}
n=\frac{1,96^{2}(0,72 \times 0,28)}{0,1^{2}} \\
n=\frac{0,77}{0,01}=77,4
\end{gathered}
$$

Dengan demikian besar sampel sesuai dengan perhitungan menggunakan rumus di atas adalah : $\mathrm{n}=77$ orang. Dilakukan penyesuaian sampel karena populasi penelitian $<10.000$

$$
\begin{gathered}
n_{1}=\frac{n}{1+\left(\frac{n}{N}\right)} \\
n_{1}=\frac{77}{1+\left(\frac{77}{158}\right)}=51,7
\end{gathered}
$$

Dari hasil perhitungan maka diperoleh besar sampel minimal sebesar 52 orang.

\section{Cara Pengambilan Sampel}

Teknik pengambilan sampel yang digunakan adalah nonprobability sampling dengan teknik consecutive sampling, yaitu suatu teknik penetapan sampel dengan memasukkan semua sampel penelitian yang datang dan memenuhi kriteria inklusi sample dan responden dalam kurun 
waktu tertentu hingga jumlah minimal sampel dapat terpenuhi.

\section{Responden}

Responden adalah ibu yang memiliki balita usia $>6$ bulan hingga 24 bulan yang terpilih sesuai dengan kriteria inklusi dalam penelitian kemudian ditetapkan sebagai responden dalam memperoleh informasi mengenai hal-hal terkait variabel penelitian.

\section{Variabel Penelitian}

Adapun variabel yang digunakan dalam penelitian ini yaitu:

1.Karakteristik ibu :

$$
\begin{aligned}
& \text {-Usia ibu } \\
& \text {-Tingkat pengetahuan ibu } \\
& \text {-Tingkat pendidikan ibu } \\
& \text {-Pekerjaan ibu } \\
& \text {-Paritas ibu } \\
& \text {-Penghasilan keluarga } \\
& \text {-Dukungan suami } \\
& \text {-Dukungan petugas kesehatan }
\end{aligned}
$$

\section{Proporsi pemberian ASI Eksklusif}

\section{Definisi Operasional Variabel Penelitian}

1. Usia ibu adalah usia responden yang dihitung sejak lahir sampai ulang tahun terakhir. Usia ibu diperoleh dari wawancara terstruktur (kuisioner) ataupun dengan melihat KTP ibu jika ibu lupa dengan usianya.

2. Tingkat pengetahuan ibu adalah hasil pemikiran dari responden mengenai ASI eksklusif meliputi pola pemberian ASI eksklusif dan manfaat ASI eksklusif. Pengetahuan ibu diperoleh melalui wawancara terstruktur (kuisioner).

3. Tingkat pendidikan ibu adalah pendidikan formal tertinggi yang pernah diselesaikan responden pada institusi atau lembaga yang diakui oleh pemerintah. Pendidikan ibu diperoleh dari wawancara terstruktur (kuisioner).

4. Pekerjaan ibu adalah jenis kegiatan yang dilakukan oleh ibu yang menghabiskan waktu paling banyak, yang meliputi jenis pekerjaan ibu (dikategorikan menjadi ibu rumah tangga, Pegawai Negeri Sipil (PNS), pegawai swasta, wirasawasta, dan petani/nelayan/buruh). Data diperoleh melalui wawancara terstruktur (kuisioner).
5. Paritas adalah banyaknya anak yang dimiliki responden. Jumlah anak diperoleh melalui wawancara terstruktur (kuisioner).

6. Penghasilan keluarga adalah total penghasilan keluarga termasuk ayah dan ibu yang bekerja selama 1 bulan. Data diperoleh melalui wawancara terstruktur (kuisioner).

7. Dukungan keluarga adalah segala macam upaya yang diberikan oleh keluarga kepada ibu saat memberikan ASI eksklusif baik berupa dukungan informasional, dukungan penghargaan, dukungan instrumental, dan dukungan emosional. Data diperoleh melalui wawancara terstruktur (kuisioner). ).

8. Dukungan petugas kesehatan adalah segala macam upaya yang diberikan oleh petugas kesehatan kepada ibu saat memberikan ASI eksklusif baik berupa dukungan informasional, dukungan penghargaan, dukungan instrumental, dan dukungan emosional. Data diperoleh melalui wawancara terstruktur (kuisioner). ).

9. Pemberian ASI eksklusif adalah pemberian ASI saja pada bayi usia 0-6 bulan tanpa memberikan makanan ataupun minuman lainnya termasuk air putih. Pemberian ASI diperoleh melalui wawancara terstruktur (kuisioner).

\section{Cara dan Instrumen Pengumpulan Data}

Pengumpulan data dilakukan dengan cara wawancara terstruktur dengan menggunakan kuisioner pada ibu yang memiliki bayi usia $>6$ bulan hingga 24 bulan di desa Pekutatan. Sebelum wawancara dilakukan, subjek penelitian dimintai persetujuan terlebih dahulu apakah bersedia untuk dilakukan wawancara atau tidak. Jika subjek penelitian bersedia untuk dilakukan wawancara, selanjutnya subjek penelitian diwawancarai secara terstruktur berdasarkan kuisioner yang tersedia.

Instrument yang digunakan dalam penelitian ini, yaitu kuisioner untuk pengumpul data, kalkulator dan alat-alat tulis.

\section{Analisis Data}

Sebelum melakukan analisis data, akan dilakukan data entry yang sebelumnya telah melalui tahap coding dan editing, kemudian dilanjutkan dengan data cleaning yang dilakukan terhadap semua variabel untuk mengetahui data yang tidak sesuai 
(missing) sehingga akan diperoleh data yang baik untuk dianalisis. Analisis data dilakukan dengan menggunakan software program statistik SPSS 17 for Windows. Data yang diperoleh dianalisis secara deskriptif

\section{HASIL DAN PEMBAHASAN}

\section{Karakteristik Responden}

Responden pada penelitian ini sebanyak 52 orang dari seluruh ibu menyusui yang memiliki balita usia $>6$ bulan hingga 24 bulan yang bertempat tinggal di kecamatan Pekutatan. Karakteristik individu ibu menyusui yang diteliti dalam penelitian ini menurut: Usia, tingkat pendidikan, pekerjaan, penghasilan keluarga, paritas, tingkat pengetahuan, dukungan suami, dan dukungan petugas kesehatan

\section{Distribusi Responden Berdasarkan Usia}

Pada Tabel 1 memperlihatkan distribusi responden berdasarkan usia. Hasil penelitian menunjukkan bahwa kelompok usia responden yang paling banyak adalah usia 18-30 tahun yakni sebanyak 40 orang (76,9\%), sedangkan kelompok usia $\leq 18$ tahun sebanyak 1 orang (1,9\%) dan kelompok usia $\geq 30$ tahun sebanyak 11 orang $(21,2 \%)$.

Tabel 1. Distribusi Responden Berdasarkan Usia di Kecamatan Pekutatan

\begin{tabular}{|lll|}
\hline Kelompok Usia & Jumlah & Persentase (\%) \\
\hline$\leq 18$ tahun & 1 & 1,9 \\
$18-30$ tahun & 40 & 76,9 \\
$\geq 30$ tahun & 11 & 21,2 \\
\hline Jumlah & 52 & 100 \\
\hline
\end{tabular}

\section{Distribusi Responden Berdasarkan Pendidikan}

Pada Tabel 2 memperlihatkan distribusi responden berdasarkan pendidikan. Hasil penelitian menunjukkan bahwa kelompok pendidikan responden yang paling banyak adalah tamat SMA/sederajat yakni sebanyak 25 orang $(48,1 \%)$, sedangkan kelompok tamat SD/sederajat sebanyak 2 orang $(3,8 \%)$, kelompok tamat SMP/sederajat 18 orang (34,6\%) dan kelompok tamat diploma/pendidikan tinggi sebanyak 7 orang $(13,5 \%)$.

Tabel 2. Distribusi Responden Berdasarkan Tingkat Pendidikan di Kecamatan Pekutatan

\begin{tabular}{|lll|}
\hline Pendidikan & Jumlah & (\%) \\
\hline Tidak sekolah/tidak tamat SD & 0 & 0 \\
Tamat SD/sederajat & 2 & 3,8 \\
Tamat SMP/sederajat & 18 & 34,6 \\
Tamat SMA/sederajat & 25 & 48,1 \\
Tamat diploma / perguruan & 7 & 13,5 \\
tinggi & & \\
\hline Jumlah & 52 & 100 \\
\hline
\end{tabular}

\section{Distribusi Responden Berdasarkan Pekerjaan}

Berdasarkan tabel 3 dapat diketahui bahwa responden lebih banyak tidak berkerja atau ibu rumah tangga yaitu sebanyak 23 orang (44,2\%), sedangkan responden yang bekerja sebagai petani adalah 4 orang (7,7\%), pekerja buruh adalah 2 orang $(3,8 \%)$, Pedagang adalah 5 orang $(9,6 \%)$, pegawai swasta $14(26,9 \%)$, PNS adalah 3 orang $(5,8 \%)$ sedangkan lain- lain adalah adalah 1 (1,9\%).

Tabel 3. Distribusi Responden Berdasarkan Pekerjaan di Kecamatan Pekutatan

\begin{tabular}{|c|c|c|}
\hline Pekerjaan & Jumlah & (\%) \\
\hline Tidak berkerja/ibu rumah & 23 & 44,2 \\
\hline tangga & 4 & 7,7 \\
\hline Petani & 2 & 3,8 \\
\hline Buruh & 5 & 9,6 \\
\hline Pedagang & 14 & 26,9 \\
\hline Pegawai swasta & 3 & 5,8 \\
\hline \multicolumn{3}{|l|}{ PNS } \\
\hline Lainnya & 1 & 1,9 \\
\hline Jumlah & 52 & 100 \\
\hline
\end{tabular}

\section{Distribusi Responden Berdasarkan Penghasilan Keluarga}

Pada tabel 4 menguraikan bahwa hasil penelitian ini memiliki responden dengan penghasilan keluarga per bulan yang rendah atau $\leq 1.622 .000$ yaitu sebanyak 3 orang $(5,8 \%)$ dan yang berpenghasilan $>1.622 .000$ sebanyak 49 orang (94,2\%).

Tabel 4. Distribusi Responden Berdasarkan Penghasilan Keluarga di Kecamatan Pekutatan

\begin{tabular}{|lcc|}
\hline Penghasilan Per Bulan & Jumlah & $\begin{array}{c}\text { Persentase } \\
(\%)\end{array}$ \\
\hline $\mathrm{Rp} \leq 1.622 .000$ & 3 & 5,8 \\
$\mathrm{Rp}>1.622 .000$ & 49 & 94,2 \\
\hline Jumlah & 52 & 100 \\
\hline
\end{tabular}




\section{Distribusi Responden Berdasarkan Paritas}

Berdasarkan tabel 7 dapat diketahui bahwa jumlah anak yang dimiliki responden lebih banyak $\leq 2$ yaitu sebanyak 33 orang $(63,5 \%)$, sedangkan jumlah anak >2 lebih sedikit yaitu sebanyak 19 orang $(36,5 \%)$.

Tabel 5. Distribusi Responden Berdasarkan Paritas di Kecamatan Pekutatan

\begin{tabular}{|ccc|}
\hline Paritas & Jumlah & Persentase (\%) \\
\hline$\leq 2$ & 33 & 63,5 \\
$>2$ & 19 & 36,5 \\
\hline Jumlah & 52 & 100 \\
\hline
\end{tabular}

\section{Distribusi Responden Berdasarkan Tingkat Pengetahuan}

Hasil penelitian tentang pengetahuan ibu menyusui mengenai ASI eksklusif ditampilkan pada tabel 3. Pada tabel tersebut diperoleh bahwa 42 orang $(80,8 \%)$ yang memiliki pengetahuan baik dan sisanya yaitu 10 orang $(19,2 \%)$ memiliki pengetahuan kurang.

Tabel 6. Distribusi Responden Berdasarkan Tingkat Pengetahuan di Kecamatan Pekutatan

\begin{tabular}{|ccc|}
\hline $\begin{array}{c}\text { Tingkat } \\
\text { Pengetahuan }\end{array}$ & Jumlah & Persentase (\%) \\
\hline Baik & 42 & 80,8 \\
Kurang & 10 & 19,2 \\
\hline Jumlah & 52 & 100 \\
\hline
\end{tabular}

Tabel 7. Distribusi Responden Berdasarkan Jawaban Pertanyaan Tingkat Pengetahuan di Kecamatan Pekutatan

\begin{tabular}{|c|c|c|c|}
\hline No & $\begin{array}{l}\text { Daftar Pertanyaan } \\
\text { Pengetahuan }\end{array}$ & Benar & Salah \\
\hline 1. & $\begin{array}{c}\text { Pengetahuan responden } \\
\text { mengenai lama } \\
\text { pemberian ASI Eksklusif }\end{array}$ & $\begin{array}{c}25 \\
(48,1 \%)\end{array}$ & $\begin{array}{c}27 \\
(51,9 \%)\end{array}$ \\
\hline 2. & $\begin{array}{l}\text { Pengetahuan responden } \\
\text { mengenai Kolostrum }\end{array}$ & $\begin{array}{c}45 \\
(86,5 \%)\end{array}$ & $\begin{array}{c}7 \\
(13,5 \%)\end{array}$ \\
\hline 3. & $\begin{array}{c}\text { Pengetahuan mengenai } \\
\text { keuntungan menyusui } \\
\text { bagi ibu }\end{array}$ & $\begin{array}{c}49 \\
(94,2 \%)\end{array}$ & $\begin{array}{c}3 \\
(5,8 \%)\end{array}$ \\
\hline 4. & $\begin{array}{c}\text { Pengetahuan mengenai } \\
\text { penyimpanan ASI }\end{array}$ & $\begin{array}{c}38 \\
(73,6 \%)\end{array}$ & $\begin{array}{c}14 \\
(26,9 \%)\end{array}$ \\
\hline 5. & $\begin{array}{l}\text { Pengetahuan responden } \\
\text { mengenai lama } \\
\text { penyimpanan ASI di luar }\end{array}$ & $\begin{array}{c}30 \\
(57,7 \%)\end{array}$ & $\begin{array}{c}22 \\
(42,3 \%)\end{array}$ \\
\hline 6. & $\begin{array}{c}\text { Pengetahuan responden } \\
\text { mengenai kelebihan ASI } \\
\text { Eksklusif }\end{array}$ & $\begin{array}{c}51 \\
(98,1 \%)\end{array}$ & $\begin{array}{c}1 \\
(1,9 \%)\end{array}$ \\
\hline 7. & $\begin{array}{c}\text { Pengetahuan responden } \\
\text { mengenai frekuensi } \\
\text { pemberian ASI Eksklusif }\end{array}$ & $\begin{array}{c}40 \\
(76,9 \%)\end{array}$ & $\begin{array}{c}12 \\
(23,1 \%)\end{array}$ \\
\hline 8. & $\begin{array}{l}\text { Pengetahuan responden } \\
\text { mengenai keuntungan } \\
\text { menyusu bagi bayi }\end{array}$ & $\begin{array}{c}52 \\
(100 \%)\end{array}$ & $\begin{array}{c}0 \\
(0 \%)\end{array}$ \\
\hline 9. & $\begin{array}{c}\text { Pengetahuan responden } \\
\text { mengenai lama } \\
\text { penyimpanan ASI di } \\
\text { kulkas }\end{array}$ & $\begin{array}{c}31 \\
(59,6 \%)\end{array}$ & $\begin{array}{c}21 \\
(40,4 \%)\end{array}$ \\
\hline
\end{tabular}

\section{Distribusi Responden Berdasarkan Dukungan suami}

Hasil penelitian ini menunjukkan bahwa sebagian besar responden mendapat dukungan baik dari suami yakni sebanyak 28 orang $(53,8 \%)$, sedangkan sebanyak 24 orang $(46,2 \%)$ mendapat dukungan keluarga yang kurang terhadap pemberian ASI eksklusif.

Tabel 8. Distribusi Responden Berdasarkan Dukungan Suami di Desa Pekutatan Pekutatan

\begin{tabular}{|ccc|}
\hline $\begin{array}{c}\text { Dukungan } \\
\text { Suami }\end{array}$ & Jumlah & Persentase (\%) \\
\hline Baik & 28 & 53,8 \\
Kurang & 24 & 46,2 \\
\hline Jumlah & 52 & 100 \\
\hline
\end{tabular}


Tabel 9. Distribusi Responden Berdasarkan Jawaban Pertanyaan berdasarkan dukungan suami di Desa Pekutatan.

\begin{tabular}{|c|c|c|c|}
\hline No & $\begin{array}{l}\text { Daftar Pertanyaan } \\
\text { Pengetahuan }\end{array}$ & Benar & Salah \\
\hline 1. & $\begin{array}{l}\text { Suami menyarankan } \\
\text { ASI }\end{array}$ & $\begin{array}{l}48 \\
(92,3 \%)\end{array}$ & $\begin{array}{l}4 \\
(7,7 \%)\end{array}$ \\
\hline 2. & $\begin{array}{l}\text { Suami memberitahu } \\
\text { maanfaat ASI dan cara } \\
\text { menyusui yang benar }\end{array}$ & $\begin{array}{l}33 \\
(63,5 \%)\end{array}$ & $\begin{array}{l}19 \\
(36,5 \%)\end{array}$ \\
\hline 3. & $\begin{array}{l}\text { Suami mengingatkan } \\
\text { jadwal ASI }\end{array}$ & $\begin{array}{l}22 \\
(42,3 \%)\end{array}$ & $\begin{array}{l}30 \\
(57,7 \%)\end{array}$ \\
\hline 4. & $\begin{array}{l}\text { Suami menegur jika } \\
\text { memberikan } \\
\text { makanan/minuman } \\
\text { selain ASI }\end{array}$ & $\begin{array}{l}24 \\
(46,2 \%)\end{array}$ & $\begin{array}{l}28 \\
(53,8 \%)\end{array}$ \\
\hline 5. & $\begin{array}{l}\text { Suami menyediakan } \\
\text { uang cukup }\end{array}$ & $\begin{array}{l}50 \\
(96,2 \%)\end{array}$ & $\begin{array}{l}2 \\
(3,8 \%)\end{array}$ \\
\hline 6. & $\begin{array}{l}\text { Suami menyediakan } \\
\text { makanan dan } \\
\text { minuman bergizi }\end{array}$ & $\begin{array}{l}38 \\
(73,1 \%)\end{array}$ & $\begin{array}{l}14 \\
(26,9 \%)\end{array}$ \\
\hline 7. & $\begin{array}{l}\text { Suami mendampingi } \\
\text { saat menyusui }\end{array}$ & $\begin{array}{l}20 \\
(38,5 \%)\end{array}$ & $\begin{array}{l}32 \\
(61,5 \%)\end{array}$ \\
\hline 8. & $\begin{array}{l}\text { Suami membantu jika } \\
\text { menyusui tengah } \\
\text { malam }\end{array}$ & $\begin{array}{l}19 \\
(36,5 \%)\end{array}$ & $\begin{array}{l}33 \\
(63,5 \%)\end{array}$ \\
\hline 9. & $\begin{array}{l}\text { Nyaman jika ditemani } \\
\text { oleh suami saat } \\
\text { menyusui }\end{array}$ & $\begin{array}{l}43 \\
(82,7 \%)\end{array}$ & $\begin{array}{l}9 \\
(17,3 \%)\end{array}$ \\
\hline 10. & $\begin{array}{l}\text { Suami membantu } \\
\text { mengurus bayi }\end{array}$ & $\begin{array}{l}39 \\
(75 \%)\end{array}$ & $\begin{array}{l}13 \\
(25 \%)\end{array}$ \\
\hline
\end{tabular}

Distribusi Responden Berdasarkan Dukungan Petugas Kesehatan

Hasil penelitian ini menunjukkan bahwa sebagian besar responden mendapat dukungan baik dari Petugas Kesehatan yakni sebanyak 41 orang (78,8\%), sedangkan sebanyak 11 orang $(21,2 \%)$ mendapat dukungan petugas kesehatan yang kurang terhadap pemberian ASI eksklusif.

Tabel 10. Distribusi Responden Berdasarkan Dukungan Petugas Kesehatan di Desa Pekutatan

\begin{tabular}{|ccc|}
\hline Dukungan petugas & Jumlah & Persentase (\%) \\
\hline Baik & 41 & 78,8 \\
Kurang & 11 & 21,2 \\
\hline Jumlah & 52 & 100 \\
\hline
\end{tabular}

Tabel 11. Distribusi Responden Berdasarkan Jawaban Pertanyaan berdasarkan dukungan Petugas Kesehatan di Desa Pekutatan

\begin{tabular}{|llll|}
\hline No & $\begin{array}{l}\text { Daftar Pertanyaan } \\
\text { Pengetahuan }\end{array}$ & Ya & Tidak \\
\hline 1. & $\begin{array}{l}\text { Pernah disarankan } \\
\text { ASI eksklusif }\end{array}$ & $(100 \%)$ & $(0 \%)$ \\
2. & $\begin{array}{l}\text { Pernah } \\
\text { mendapatkan }\end{array}$ & 40 & 12 \\
& $\begin{array}{l}\text { penyuluhan tentang } \\
\text { ASI eksklusif }\end{array}$ & & \\
3. & Pernah diajak \\
berdiskusi tentang & $(28,9 \%)$ \\
masalah menyusui & & 24 \\
& yang dihadapi & $(46,2 \%)$ \\
\hline
\end{tabular}

\section{Proporsi Pemberian ASI Eksklusif}

Berdasarkan hasil penelitian ini dapat diketahui bahwa sebanyak 36 orang (69,2\%) tidak memberikan ASI Eksklusif dan hanya 16 orang (30,8\%) yang memberikan ASI Eksklusif kepada bayi mereka. Distribusi responden berdasarkan pemberian ASI Eksklusif dapat dilihat pada tabel 10.

Tabel 12. Proporsi Pemberian ASI Eksklusif di Desa Pekutatan

\begin{tabular}{|c|c|c|c|}
\hline $\begin{array}{l}\text { Pemberian } \\
\text { Eksklusif }\end{array}$ & ASI & Jumlah & $\begin{array}{l}\text { Persentase } \\
\text { (\%) }\end{array}$ \\
\hline ASI eksklusif & & 16 & 30,8 \\
\hline Tidak ASI eksklusif & & 36 & 69,2 \\
\hline Jumlah & & 52 & 100 \\
\hline
\end{tabular}

\section{Proporsi Pemberian ASI Eksklusif Berdasarkan Usia Ibu}

Tabel 13. Proporsi Pemberian ASI Eksklusif Berdasarkan Usia Ibu di Desa Pekutatan

\begin{tabular}{|c|c|c|c|}
\hline \multirow[b]{2}{*}{ Umur Ibu } & \multicolumn{2}{|c|}{ Pemberian ASI Eksklusif } & \multirow[b]{2}{*}{ Total } \\
\hline & Eksklusif & $\begin{array}{l}\text { Tidak } \\
\text { Eksklusif }\end{array}$ & \\
\hline$<18$ tahun & $0(0 \%)$ & 1 & 1 \\
\hline $\begin{array}{l}18-30 \\
\text { tahun }\end{array}$ & $13(32,5 \%)$ & $27(67,5 \%)$ & 40 \\
\hline$>30$ & $3(27,2 \%)$ & $8(72,8 \%)$ & 11 \\
\hline Jumlah & $16(30,8 \%)$ & $36(69,2 \%)$ & 52 \\
\hline
\end{tabular}

Berdasarkan tabel 13 di atas, terlihat bahwa dari ibu yang berusia < 18 tahun sedangkan tidak 
memberikann ASI eksklusif. Dari 40 responden yang berusia 18-30 tahun hanya 13 orang $(32,5 \%) y a n g$ memberikan ASI secara eksklusif dan 27 orang $(67,5 \%)$ yang tidak memberikan ASI eksklusif. Pada seluruh responden dengan kategori berusia > 30 tahun, hanya 3 orang $(27,2 \%)$ yang memberikan ASI eksklusif.

\section{Proporsi Pemberian ASI Eksklusif Berdasarkan Tingkat Pendidikan Ibu}

Pada tabel 14, proporsi pemberian ASI eksklusif berdasarkan pendidikan diperoleh bahwa ibu yang berpendidikan lebih tinggi yang memberikan ASI eksklusif sebanyak 34,3\%, sedangkan ibu yang berpendidikan lebih rendah hanya $25 \%$ yang memberikan ASI eksklusif. Berdasarkan data tersebut dapat dilihat bahwa kecenderungan proporsi pemberian ASI eksklusif lebih banyak terdapat pada ibu-ibu yang berpendidikan lebih tinggi (SMA ke atas).

Tabel 14. Proporsi Pemberian ASI Eksklusif Berdasarkan Tingkat Pendidikan Ibu di Desa Pekutatan

\begin{tabular}{|llll|}
\hline \multirow{2}{*}{ Pendidikan } & \multicolumn{2}{l}{ Pemberian ASI Eksklusif } & \\
\cline { 2 - 3 } & Eksklusif & \multicolumn{2}{l|}{$\begin{array}{l}\text { Tidak } \\
\text { Eksklusif }\end{array}$} \\
\hline Wajib & $5(25 \%)$ & $15(75 \%)$ & 20 \\
Lanjutan & $11(34,3 \%)$ & $21(65,7 \%)$ & 32 \\
\hline Jumlah & $16(30,8 \%)$ & $36(69,2 \%)$ & 52 \\
\hline
\end{tabular}

Proporsi Pemberian ASI Eksklusif Berdasarkan Pekerjaan Ibu

Tabel 15. Proporsi Pemberian ASI Eksklusif Berdasarkan Pekerjaan Ibu di Desa Pekutatan

\begin{tabular}{|llll|}
\hline $\begin{array}{l}\text { Status } \\
\text { Pekerjaan } \\
\text { Ibu }\end{array}$ & \multicolumn{2}{l}{ Pemberian ASI Eksklusif } & \\
\cline { 2 - 3 } & Eksklusif & $\begin{array}{l}\text { Tidak } \\
\text { Eksklusif }\end{array}$ & \\
\hline Bekerja & $10(34,4 \%)$ & $19(65,6 \%)$ & 29 \\
$\begin{array}{l}\text { Tidak } \\
\text { Bekerja }\end{array}$ & $6(35,2 \%)$ & $17(64,8 \%)$ & 71 \\
\hline Jumlah & $16(30,8 \%)$ & $36(69,2 \%)$ & 52 \\
\hline
\end{tabular}

Berdasarkan tabel 16 di atas, diketahui bahwa dari seluruh ibu yang tidak bekerja yang memberikan ASI eksklusif sebanyak 6 orang $(35,2 \%)$, sedangkan dari 29 orang ibu yang bekerja yang memberikan
ASI eksklusif hanya 10 orang (34,4\%). Dari hasil tersebut maka dapat dilihat kecenderungan ibu yang tidak bekerja dapat memberikan ASI eksklusif lebih besar dibandingkan dengan ibu yang bekerja.

\section{Proporsi Pemberian ASI Eksklusif Berdasarkan Penghasilan Keluarga}

Tabel 16. Proporsi Pemberian ASI Eksklusif Berdasarkan Penghasilan Keluarga di Desa Pekutatan

\begin{tabular}{|llll|}
\hline $\begin{array}{l}\text { Penghasilan } \\
\text { Keluarga }\end{array}$ & \multicolumn{2}{l}{ Pemberian ASI Eksklusif } & \\
\cline { 2 - 3 } & Eksklusif & \multicolumn{2}{l|}{$\begin{array}{l}\text { Tidak } \\
\text { Eksklusif }\end{array}$} \\
\hline Rendah & $2(66,7 \%)$ & $1(33,3 \%)$ & 3 \\
Tinggi & $14(28,5 \%)$ & $35(71,5 \%)$ & 49 \\
\hline Jumlah & $16(30,8 \%)$ & $36(69,2 \%)$ & 52 \\
\hline
\end{tabular}

Pada tabel 18 diatas, proporsi ibu berdasarkan penghasilan keluarga dengan perilaku pemberian ASI eksklusif diperoleh bahwa dari seluruh ibu yang keluarganya memiliki penghasilan rendah yang memberikan ASI eksklusif sebanyak 66,7\%, sedangkan pada ibu yang penghasilan keluarganya tinggi hanya $28,5 \%$ yang memberikan ASI eksklusif. Dari hasil tersebut dapat dilihat bahwa proporsi pemberian ASI eksklusif lebih besar pada ibu-ibu yang memiliki penghasilan keluarga yang rendah.

\section{Proporsi Pemberian ASI Eksklusif Berdasarkan Paritas Ibu}

Tabel 17. Proporsi Pemberian ASI Eksklusif Berdasarkan Paritas Ibu di Desa Pekutatan

\begin{tabular}{|llll|}
\hline \multirow{2}{*}{$\begin{array}{l}\text { Jumlah } \\
\text { Anak }\end{array}$} & \multicolumn{2}{l}{ Pemberian ASI Eksklusif } & \\
\cline { 2 - 3 } & Eksklusif & $\begin{array}{l}\text { Tidak } \\
\text { Eksklusif }\end{array}$ & Total \\
\hline$\leq 2$ & $11(33,3 \%)$ & $22(66,7 \%)$ & 33 \\
$>2$ & $5(26,3 \%)$ & $14(73,7 \%)$ & 19 \\
\hline Jumlah & $16(30,8 \%)$ & $36(69,2 \%)$ & 52 \\
\hline
\end{tabular}

Berdasarkan tabel 17 di atas, diketahui bahwa dari seluruh ibu yang memiliki anak satu atau dua yang memberikan ASI eksklusif sebanyak 11 orang $(33,3 \%)$, sedangkan ibu yang memiliki anak lebih dari dua yang memberikan ASI eksklusif sebanyak 5 orang $(26,3 \%)$. Dari data tersebut dapat dilihat kecenderungan bahwa terdapat proporsi 
pemberian ASI eksklusif yang sedikit lebih kecil pada responden yang memiliki anak lebih dari dua.

\section{Proporsi Pemberian ASI Eksklusif Berdasarkan Pengetahuan Ibu}

Tabel 18. Proporsi Pemberian ASI Eksklusif Berdasarkan Pengetahuan Ibu di Desa Pekutatan

\begin{tabular}{|llll|}
\hline \multirow{2}{*}{$\begin{array}{l}\text { Pengetahu } \\
\text { an }\end{array}$} & \multicolumn{2}{l}{ Pemberian ASI Eksklusif } & \\
\cline { 2 - 3 } & Eksklusif & $\begin{array}{l}\text { Tidak } \\
\text { Eksklusif }\end{array}$ & \\
\hline Baik & $15(35,7 \%)$ & $27(64,3 \%)$ & 42 \\
Kurang & $1(10 \%)$ & $9(90 \%)$ & 10 \\
\hline Jumlah & $16(30,8 \%)$ & $36(69,2 \%)$ & 52 \\
\hline
\end{tabular}

Berdasarkan tabel 18, diketahui bahwa dari seluruh ibu yang memiliki pengetahuan baik yang memberikan ASI secara eksklusif sebanyak 15 orang $(35,7 \%)$, sedangkan ibu yang mempunyai pengetahuan kurang hanya $10 \%$ yang memberikan ASI secara eksklusif. Berdasarkan hasil data tersebut dapat dilihat bahwa terdapat peningkatan proporsi pemberian ASI eksklusif yang lebih besar pada responden dengan pengetahuan baik.

\section{Proporsi Pemberian ASI Eksklusif Berdasarkan Dukungan Suami}

Tabel 19. Proporsi Pemberian ASI Eksklusif Berdasarkan Dukungan Suami di Desa Pekutatan

\begin{tabular}{|llll|}
\hline \multirow{2}{*}{$\begin{array}{l}\text { Dukungan } \\
\text { Keluarga }\end{array}$} & \multicolumn{2}{l}{ Pemberian ASI Eksklusif } & \\
\cline { 2 - 3 } Eksklusif & $\begin{array}{l}\text { Tidak } \\
\text { Eksklusif }\end{array}$ & \\
\hline Baik & $9(32,1 \%)$ & $19(67,9 \%)$ & 28 \\
Kurang & $7(29,1 \%)$ & $17(60,9 \%)$ & 24 \\
\hline Jumlah & $16(30,8 \%)$ & $36(69,2 \%)$ & 52 \\
\hline
\end{tabular}

Berdasarkan tabel 19 di atas, diketahui sebanyak 9 orang $(32,1 \%)$ ibu yang mendapat dukungan suami yang baik memberikan ASI eksklusif, sedangkan dari dari seluruh ibu yang kurang mendapat dukungan yang dapat memberikan ASI eksklusif sebanyak 7 orang (29,1\%). Berdasarkan hasil tersebut dapat dikatakan bahwa ibu yang mendapat dukungan suami dengan baik dapat memberikan ASI eksklusif lebih banyak.

\section{Proporsi Pemberian ASI Eksklusif Berdasarkan Dukungan Petugas Kesehatan}

Tabel 20. Proporsi Pemberian ASI Eksklusif Berdasarkan Dukungan Petugas Kesehatan di Desa Pekutatan

\begin{tabular}{|llll|}
\hline $\begin{array}{l}\text { Dukungan } \\
\text { Petugas } \\
\text { Kesehatan }\end{array}$ & \multicolumn{2}{l}{ Pemberian ASI Eksklusif } & \\
\cline { 2 - 3 } & Eksklusif & $\begin{array}{l}\text { Tidak } \\
\text { Eksklusif }\end{array}$ & \\
\hline Baik & $14(34,1 \%)$ & $27(65,9 \%)$ & 41 \\
Kurang & $2(18,2 \%)$ & $9(72,8 \%)$ & 11 \\
\hline Jumlah & $16(30,8 \%)$ & $36(69,2 \%)$ & 52 \\
\hline
\end{tabular}

Berdasarkan tabel 19 di atas, diketahui sebanyak 14 orang $(34,1 \%)$ ibu yang mendapat dukungan yang baik dari petugas kesehatan memberikan ASI eksklusif, sedangkan yang kurang mendapat dukungan memberikan ASI eksklusif sebanyak 2 orang $(29,1 \%)$. Berdasarkan hasil tersebut dapat dikatakan bahwa ibu yang mendapat dukungan yang baik dari petugas kesehatan dapat memberikan ASI eksklusif lebih banyak.

\section{SIMPULAN}

Berdasarkan hasil penelitian yang dilakukan terhadap 52 ibu yang memiliki bayi usia $>6$ bulan hingga 24 bulan di Desa Pekutatan, Kecamatan Pekutatan, Kabupaten Jembrana Tahun 2015, tentang karakteristik sosio-demorafi ibu terhadap proporsi pemberian ASI eksklusif dapat disimpulkan sebagai berikut :

1. Karakteristik responden yaitu dari segi usia ibu yang paling banyak pada kategori usia 18-30 tahun yaitu sebanyak $76,9 \%$, dari segi tingkat pendidikan ibu yang paling banyak adalah pada tamat SMA/sederajat yaitu $48,1 \%$. Sebagian besar ibu bekerja yakni $56,8 \%$, kebanyakan dari responden memiliki anak $\leq 2$ yakni sebanyak 63,5\%. Dari segi penghasilan keluarga lebih banyak yang memiliki penghasilan keluarga tinggi yakni sebesar 94,2\%. Sebagian besar ibu mendapat dukungan yang baik dari suami sebesar $53,8 \%$ dan dari petugas kesehatan sebesar $78,8 \%$ serta memiliki tingkat pengetahuan yang baik sebanyak $91,25 \%$.

2. Terdapat 16 responden yang memberikan ASI eksklusif, sehingga diperoleh proporsi pemberian ASI eksklusif sebesar $30,8 \%$. 
3. Pemberian ASI eksklusif oleh ibu paling banyak dilakukan pada kelompok usia 18-30 tahun yakni sebesar $32,5 \%$

4. Pemberian ASI eksklusif oleh ibu lebih banyak dilakukan pada kelompok ibu yang berpendidikan tinggi yakni sebesar 34,3\%

5. Pemberian ASI eksklusif berdasarkan status pekerjaan ibu, tertinggi pada kelompok ibu yang tidak bekerja yaitu sebesar $35,2 \%$

6. Berdasarkan penghasilan keluarga, pemberian ASI ekskusif lebih besar diberikan oleh ibu yang memiliki penghasilan keluarga rendah yakni sebesar $66,7 \%$.

7. Berdasarkan paritas ibu, kelompok yang paling besar memberikan ASI eksklusif adalah ibu dengan jumlah anak $\leq 2$ yakni 33,3\%

8. Pemberian ASI eksklusif oleh ibu paling banyak dilakukan pada kelompok ibu berpengetahuan baik yakni sebesar 35,7\%.

9. Berdasarkan dukungan keluarga, pemberian ASI eksklusif lebih banyak diberikan oleh kelompok ibu yang mendapat dukungan keluarga baik yaitu sebanyak $32,1 \%$.

10. Berdasarkan dukungan petugas kesehatan, pemberian ASI eksklusif lebih banyak diberikan oleh kelompok ibu yang mendapat dukungan keluarga baik yaitu sebanyak $34,1 \%$.

\section{SARAN}

1.Diharapkan agar puskesmas tidak hanya memberikan penyuluhan kepada ibu-ibu menyusui namun juga kepada keluarga yang memiliki bayi dan ibu hamil tentang manfaat dan tujuan ASI eksklusif sehingga keluarga dapat mendorong ibu agar mau memberikan ASI eksklusif kepada bayi mereka.

2.Diharapkan agar puskesmas melakukan pembinaan secara berkesinambungan pada petugas kesehatan dari segi pengetahuan, sikap dan ketrampilan, upaya penggerakan masyarakat serta koordinasi lintas program dan lintas sektor untuk tercapainya tujuan program.

3.Diharapkan agar puskesmas memberikan dukungan program peningkatan cakupan ASI di wilayah kerjanya melalui petugas kesehatan terutama bidan desa dengan melakukan kegiatan dan melaporkan hasilnya secara rutin.

4. Untuk peneliti lain yang ingin meneliti mengenai hal yang sama, perlu ada penggalian yang lebih dalam dari masing-masing variabel sehingga mendapatkan informasi yang lebih akurat.

5. Dalam membuat program promosi kesehatan mengenai ASI di kelas ibu sebaiknya mengikut sertakan suami sebagai sasaran program.

\section{DAFTAR PUSTAKA}

1. Sriningsih, I. Faktor Demografi, Pengetahuan Ibu Tentang Air Susu Ibu Dan Pemberian ASI Eksklusif. KEMAS 2011;6(2):100-106.

2. Afrose, L., Banu, B., Ahmed, K.R. ,Khanom K. Factors Associated With Knowledge About Breastfeeding Among Female Garment Workers in Dhaka city.WHO South-East Asia Journal of Public Health 2012;1(3):249-255

3. Depkes RI. (2006). Pedoman Umum Pemberian Makanan Pendamping Air Susu Ibu (MP-ASI) Lokal Tahun 2006. Jakarta

4. World Health Organization - Department of Nutrition for Health And Development Department Of Child And Adolescent Health And Development. Nutrient Adequacy of Exclusive Breastfeeding for The Term Infant During The First Six Months of Life. Geneva. 2002.

5. Soetjiningsih, DSAK. ASI: Petunjukuntuk Tenaga Kesehatan. EGC. 1997; (2)20-21.

6. Rahmadhani E.P., Gustina L., Edison,. (2013) Hubungan Pemberian ASI Eksklusif dengan Angka Kejadian Diare Akut Pada Bayi Usia 6-1 Tahun di Puskesmas Kuranji Kota Padang. Jurnal Kesehatan Andalas

7. Ariefudin. (2010). Hubungan Pemberian ASI Eksklusif terhadap Kejadian ISPA. Studi Analitik Observasional di Posyandu Tegal Timur Kota Tegal

8. BPS. (2013). Survei Demografi dan Kesehatan Indonesia 2013. Jakarta : BPS

9. Dinas Kesehatan Provinsi Bali. (2013). Profil Kesehatan Provinsi Bali Tahun 2012. Bali : Dinkes

10. Dinas Kesehatan Provinsi Bali. (2014). Profil Kesehatan Provinsi Bali Tahun 2013. Bali : Dinkes 
11. Puskesmas Pekutatan I. Profil UPT. Puskesmas Pekutatan I Tahun 2014. Pemerintah Kabupaten Jembrana; Dinas Kesehatan; Puskesmas Pekutatan I. 2015;1-17.

12. Evareny, L . (2010). Peran Ayah dalam Praktek Menyusui. Berita Kedokteran Masyarakat, Vol. 26, No. 4, Desember 2010, hal. 187-95

13. Lestari, D., Zuraida, R., Larasati, T.A. (2013). Hubungan Tingkat Pengetahuan Ibu Tentang Air Susu Ibu dan Pekerjaan Ibu dengan Pemberian ASI Eksklusif di Kelurahan Fajar Bulan, Medical Journal of Lampung University, vol. 2, no. 4, pp. 88-99 